\title{
Burnout Moderation: Job Insecurity and Turnover Intention
}

\author{
Nur Lailya, Nanis Setyorinib, Rika Rahayuc, Widhi Ariestianti \\ Rochdianingrum $^{d}$, Marsudi Lestariningsihe, ${ }_{3} b_{s} c_{3} d_{s}{ }^{e}$ Indonesia School of \\ Economics (STIESIA) Surabaya, Jalan Menur Pumpungan No. 30 Surabaya, \\ 60118, Indonesia, Email: nurlaily@ @stiesia.ac.id, ${ }^{b}$ nanissetyorini@ stiesia.ac.id, \\ crikarahayu@stiesia.ac.id, \\ d widhiariestianti@stiesia.ac.id, \\ emarsudilestariningsih@stiesia.ac.id
}

\begin{abstract}
Unsettled status leads employees to have desires to change their jobs. In the context of organisations, higher turnover intention has been a critical phenomenon, since further problems arise from it in companies. Therefore, this study aims to investigate the effects of job security on turnover intention with burnout as the mediator. This is causality research. The population consists of nurses of private hospitals in Surabaya, Indonesia. The respondents are 202 nurses. The data in this study was primarily obtained using questionnaires. The data was analysed using Partial Least Square (PLS) and Sobel tests to determine the indirect effects. This study indicates that job insecurity affects turnover intention, job burnout, and burnout affected turnover intensions. A Sobel test determined that burnout could mediate the effect of job security on turnover intentions. The employees who experienced job insecurity tended to have higher levels of intention to leave the organisation. Moreover, burnout was found to be a mediating variable between job insecurity and intention to quit. Hence, increasing job insecurity encouraged higher levels of employee burnout, and subsequently increased the intention to find alternative employment.
\end{abstract}

Key words: Job Insecurity, Burnout, Turnover Intensions, Nurses, Hospitals.

\section{Introduction}

Developing companies require more new employees due to larger and more multifaceted issues. However, many companies intend to hire non-permanent employees who annually renew their contracts when they are entitled to having good jobs or when the companies still need the employees. On the other hand, contracted employees often leave their jobs because of their unsettled working status. In other words, the employees have an intention to find an 
International Journal of Innovation, Creativity and Change. www.ijicc.net

Volume 12, Issue 6, 2020

alternative job.

Turnover intention is defined as an employee's subjective plan to leave an organisation in the near future. Referring to Staw (1980), it involves both positive and negative effects for the organisation. It is a negative consequence when the organisation has compensated sufficient costs for employment substitution. This involves the time required time for recruitment, and the arrangement of particular activities to determine administrative responsibilities. The reasons for turnover intentions are often unknown (Firth et al., 2004). This phenomenon is difficult to understand, owing to psychological processes that underlie unclear organisational retractions. Turnover intentions occur when employees feel insecure in a job, when they have uncertain conditions for their future work, and when they are unsure about rewards and working periods in the company. If such insecurities continuously exist, the work quality of employees will be decreased. Job insecurity, along with other stressors, will affect employees' desires to quit their jobs (turnover intention).

Job insecurity is regarded by Greenhalgh and Rosenblatt (1984) as an individual's lack of power to maintain stability among threatened work conditions. Employees with the pressure of job insecurity normally have rational reasons to look for an alternative job that is perceived as having continuity and providing security for their careers. Employees' unsafe feelings impact their job attitudes, decrease commitment, and create a greater desire to change work. To reduce these perceptions, cautious implementation and good communication need to be restructured into stages (Kinnunen 2000).

In addition, a study of Ismail (2015) involving banking employees indicates positive and significant impacts of Job Security on intention to quit. When employees feel unsafe at work due to their unclear status (not having permanent work), they experience work fatigue (burnout). This psychological factor (work fatigue) is due to prolonged stress in the workplace (Tamini \& Kord, 2011). Experiencing work exhaustion leads employees to feel unsuited to their current workplace, so they have a desire to leave their company (turnover intention). Burnout itself has a negative impact on individuals who experience it. According to Schermerhorn (2005), the impact of burnout can decrease productivity. A strong stress reaction generates change, absence, error, accidence, dissatisfaction, and decreasing performance. Ismail (2015) also found that there were significant and positive impacts of burnout on intention to quit. Other research on burnout can be associated with increasing absenteeism and the intention to leave work (Ali et al., 2012; Thomas \& Cornelius, 2010; Marjukka et al., 2009; Faloye et al., 2013; Swider \& Zimmerman, 2010; Maslach et al., 2001; Hasan et al., 2012). Research results have indicated the significant relationships between burnout and turnover intentions.

Furthermore, employees in the field of medical services are the forefront of a hospital's 
International Journal of Innovation, Creativity and Change. www.ijicc.net Volume 12, Issue 6, 2020

success. Nurses who are directly in contact with patients are required to have nursing skills, readiness, patience, and high creativity in providing services to patients. In this study, a limitation of the problem was nurses who work at non-government hospitals in Surabaya. They were indicated as non-permanent employees with inconsistent or changeable workinghours or shift work following regulations. Therefore, the research questions of this study involve whether job security affects the turnover intentions of nurses in Surabaya and the nurses' burnout as a mediator.

\section{Figure 1}

Conceptual Framework

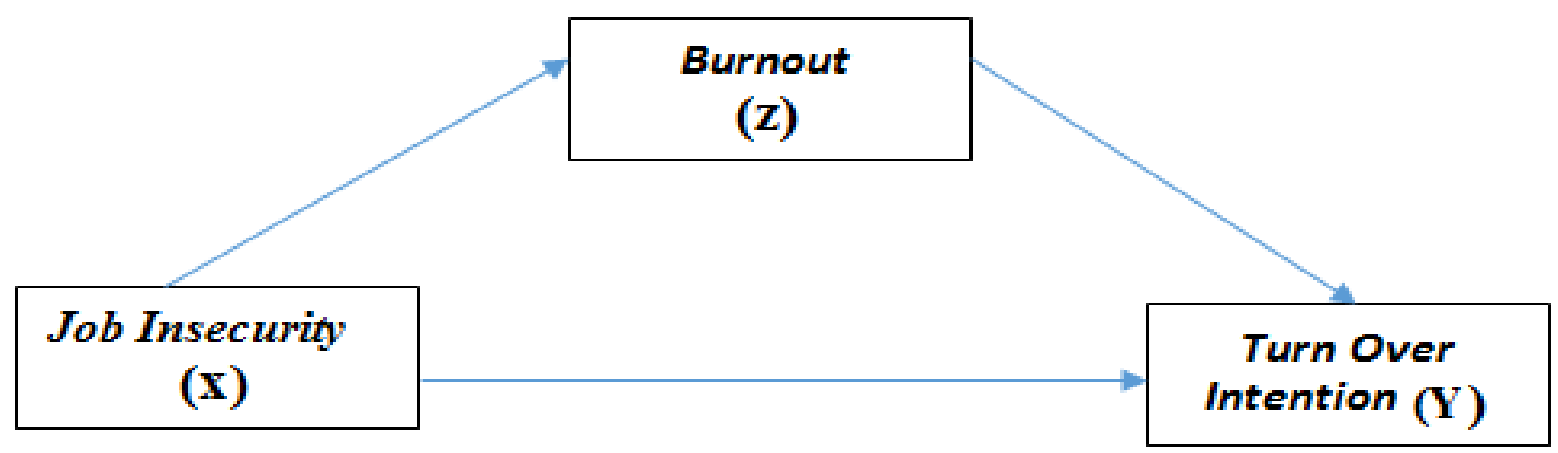

In this study, the hypotheses that are tested are as follows:

H1: Job insecurity affects turnover intention.

H2: Job insecurity affects burnout.

H3: Burnout significantly affects turnover intention.

H4: Job insecurity indirectly affects turnover intention through burnout.

\section{Methodology}

This study applied causality research. Testing hypotheses involved considering the effect of independent variables on the dependent variable. The study was conducted in Surabaya in 2019. The population was nurses with the status of non-permanent employees in ten nongovernment hospitals in Surabaya, Indonesia. The samples of this study were 202 respondents. Moreover, the data was analysed using a Partial Least Square (PLS) approach. According to Ghozali (2005), PLS aims to assist researchers for predictive purposes. Its formal model delineates latent variables as aggregate linear indicators. Weight estimates create scoring components for latent variables that can be based on inner models and outer models. Moreover, a Sobel test was applied to test the indirect effects. 
International Journal of Innovation, Creativity and Change. www.ijicc.net

Volume 12, Issue 6, 2020

\section{Results}

In this study, the analysis using Partial Least Square (PLS) determined the effect of job security on turnover intention through burnout in two models, i.e. the outer model and the inner model.

\section{Outer Model Test}

The measurement model was tested with a loading factor to investigate indicator validity by looking at the convergent validity values of the indicators in the model. Each indicator in the model should meet convergent validity, which has a value of $>0.5$. All indicator items regarding the variables of job safety, burnout, and turnover intention were considered valid since the measurement construct of the convergent validity value was above 0.5 . The values of cross loadings that were inclusively obtained from the constructors were indicated as having good discrimination. The indicator correlation value of the construct was required to be greater than the correlation values between indicators and other constructs.

In this study, AVE values tested the reliability of construct variables. The construct variables had good values of discriminant validity. The AVE value is satisfactory if the value is $>0.5$. The AVE result for indicator block that measures the construct can be indicated as having a good value of discriminant validity because the value is $>0.5$. This means that all construct variables are declared reliable. A composite reliability test of the indicator block measures the construct (Ghozali, 2013). The composite reliability value of $>0.60$ is interpreted as satisfactory (Ghozali, 2013). Referring to the term of composite reliability, the overall constructs of this study meet the criteria of composite reliability since all values are $>0.60$. Therefore, each construct can be positioned as a research variable. 
International Journal of Innovation, Creativity and Change. www.ijicc.net Volume 12, Issue 6, 2020

Figure 2

Partial Least Square (PLS)

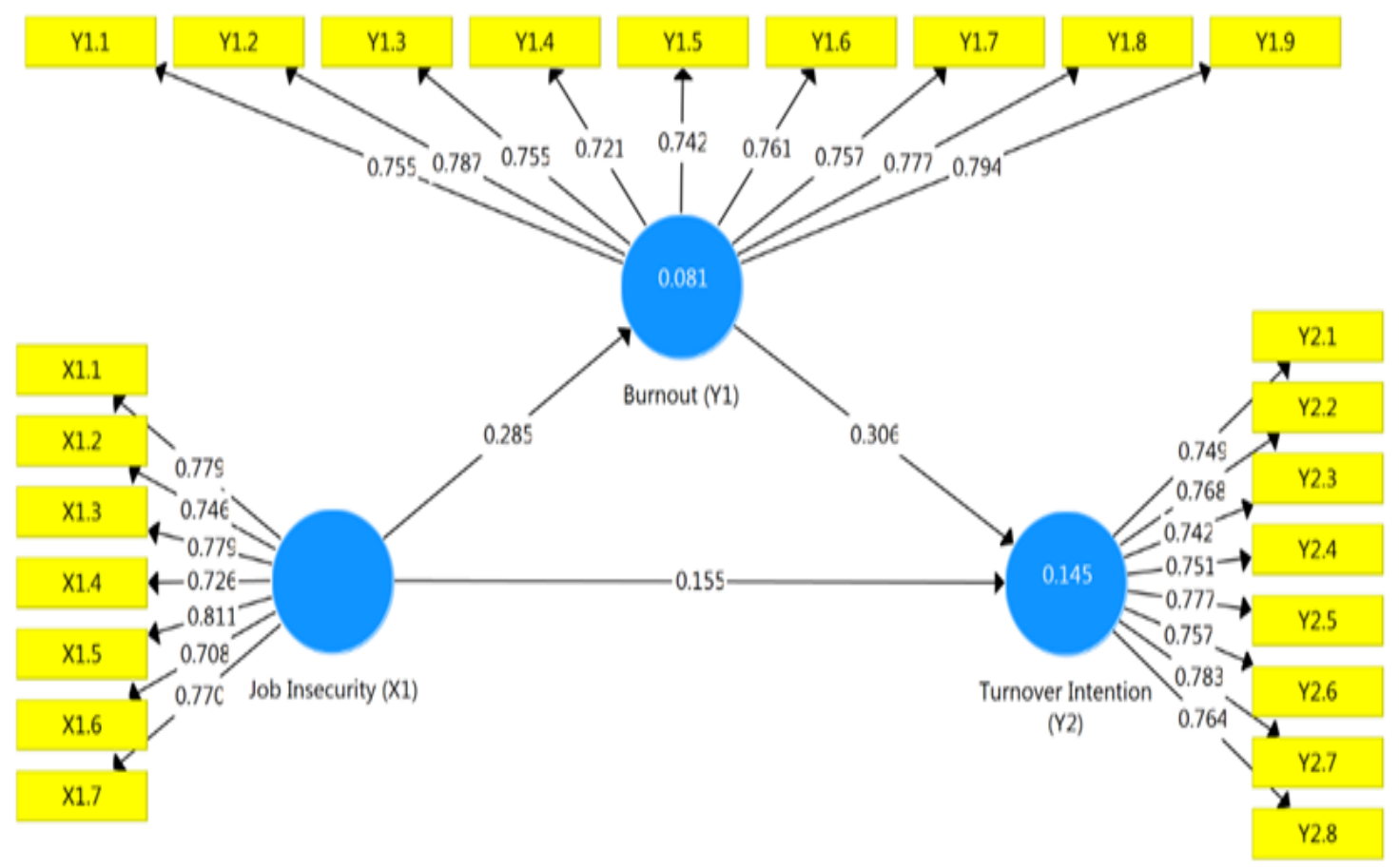

\section{Inner Model Test}

In assessing a model with PLS, R-square should be considered for each latent dependent variable.

Table 1

$R$-Square Value

\begin{tabular}{|l|l|l|}
\hline No & Variables & R-square \\
\hline 1 & Job Insecurity $(\mathrm{X})$ & \\
\hline 2 & Burnout $(\mathrm{Z})$ & 0.081 \\
\hline 3 & Turnover Intention $(\mathrm{Y})$ & 0.145 \\
\hline
\end{tabular}

The independent variable of job insecurity $(\mathrm{X})$ that affected the burnout $(\mathrm{Z})$ variable in the structural model had an R2 value of 0.081 . This indicated that the model was "weak". Job insecurity $(\mathrm{X})$ and burnout $(\mathrm{Z})$, which affected the turnover intention $(\mathrm{Y})$ variable in the structural model, indicated an R2 value of 0.145 . This showed that the model was also "weak". 
International Journal of Innovation, Creativity and Change. www.ijicc.net

Volume 12, Issue 6, 2020

Table 2

Hypotheses Testing Results

\begin{tabular}{|l|l|l|l|l|l|}
\hline & $\begin{array}{l}\text { Original sample } \\
\text { estimate }\end{array}$ & $\begin{array}{l}\text { Mean of } \\
\text { subsamples }\end{array}$ & $\begin{array}{l}\text { Standard } \\
\text { deviation }\end{array}$ & p-Value & $\begin{array}{l}\text { Deci } \\
\text { sion }\end{array}$ \\
\hline $\begin{array}{l}\text { Job Insecurity (X) } \rightarrow \\
\text { Turnover Intention (Y) }\end{array}$ & 0.155 & 0.174 & 0.070 & 2.205 & Sig \\
\hline $\begin{array}{l}\text { Job Insecurity (X) } \rightarrow \\
\text { Burnout (Z) }\end{array}$ & 0.285 & 0.298 & 0.064 & 4.447 & Sig \\
\hline $\begin{array}{l}\text { Burnout (Z) } \rightarrow \text { Turnover } \\
\text { Intention (Y) }\end{array}$ & 0.306 & 0.310 & 0.078 & 3.932 & Sig \\
\hline $\begin{array}{l}\text { Job Insecurity (X) } \rightarrow \\
\text { Burnout (Z) } \rightarrow \text { Turnover } \\
\text { Intention (Y) }\end{array}$ & 0.087 & 0.093 & 0.031 & 2.784 & Sig \\
\hline
\end{tabular}

\section{Discussion}

This study found that job insecurity had a significant effect on turnover intention. In other words, job insecurity reflected the perception of employees who were concerned about losing their job due to their current status as temporary nurses. According to Lee et al (2006), job insecurity is one of factors that prompts employees' stress because they experience uncertainty about their future work. The findings support the previous research of Williams (2003), Berntson et al. (2010), Cheng and Chan (2008), and Hasan (2015). They prove that job security has a positive relation to employees' intention to stop working. However, there is evidence supporting the positive relationships between job security and the intention to remain within an organisation (Iverson and Roy, 1994).

In addition, the hypothesis test results showed that job insecurity had a significant effect on Burnout. Hence, job insecurity generated working stress due to work fatigue. The nurses argued for having workforce saturation since they had served patients with various characters every day. Thus, the nurses working in shift could maintain their burnout in the hospital. Other research (Willliam et al., 2010) finds a positive correlation between job insecurity and burnout. Longer employment contracts had an impact on burnout (Maslach et al., 2001). Nurses who had worked for a long time and not gotten a job would experience burnout. These results support the study of William et al. (2010) and Hasan (2015), who indicate that burnout has the consequence of long-term uncertainty in relation to job insecurity.

This study also found that burnout had a significant effect on turnover intention. When nurses experienced burnout, they had an intention to leave their company. Burnout was viewed as a psychological syndrome that enhances in response to chronic interpersonal stressors in the 
International Journal of Innovation, Creativity and Change. www.ijicc.net Volume 12, Issue 6, 2020

workplace. Employees with a high level of burnout are likely to consider leaving their organisation (Maslach et al., 2001). The results are congruent with other studies indicating that burnout has an impact on employee turnover intention (Ali et al., 2012; Thomas \& Cornelius, 2010; Marjukka et al., 2009; Faloye et al., 2013; Hasan et al., 2012; Swider \& Zimmerman, 2010; Ismail, 2015).

Furthermore, this study showed that nurses who felt anxiety in their job and who experienced high levels of burnout would have increased intentions to resign from the hospital. Employees with job insecurity reported higher levels of intention to leave their organisation. Additionally, nurses' burnout was found to be a mediating variable in the relationship between job insecurity and intention to quit. In summary, the growth of job insecurity will increase burnout (William et al., 2010), and increasing work fatigue influences greater intention to find alternative work (Ali et al., 2012; Thomas and Cornelius, 2010; Marjukka et al., 2009; Faloye et al., 2013; Hasan et al., 2012; Ismail, 2015). Hence, the findings of this study provide additional evidence along with previous research.

\section{Conclusion}

This study summarised that job insecurity significantly affects the intention to leave an organisation. These results are consistent with previous research indicating that job vulnerability can be a predictor of employees' intention to quit (Berntson et al., 2010; Cheng \& Chan, 2008; Ismail, 2015). In other words, employees who feel insecure at work tend to have higher levels of intention to leave their organisation. Burnout was considered the mediating variable between job insecurity and intention to quit a company (turnover intention). Increasing job insecurity was found to advance burnout (William et al., 2010). Increasing work fatigue will result in the intention to find alternative employment (Ali et al., 2012); (Thomas and Cornelius, 2010); (Marjukka et al., 2009); (Faloye et al., 2013); (Hasan et al., 2012). The results of this study add to the evidence of the findings from previous studies.

Some companies in Indonesia likely recruit employees through contracts. As a result, employees are entitled as temporary employees. Such status affects job insecurity and lack of confidence, so employees have a desire to move to another workplace (turnover intention). If the turnover numbers are higher, the company will be harmed. Therefore, managers need to focus on antecedents of turnover intention. If job insecurity and fatigue can be identified as antecedents for employees' intentions to quit, proper HRM practices can be maintained to reduce turnover of highly qualified employees. In turn, organisations can save on financial costs and efforts for recruitment, induction, and substituted staff training. 


\section{Practical Implications}

This study has essential and practical implications, since it advises organisations against increasing job insecurity among employees. Realistic communication, human relations, mutual trust, mentoring relationships with supervisors, organisational support, information sharing, input for decision making, workshops for discussion, effective feedback, flexible work arrangements, career advisors, perceived justice, relaxation, time management, awareness of work, and so on can help employees overcome their insecurities and reduce their fatigue. Moreover, managers should deliver employees a clear message: the organisation is responsible for and respects its employees. Overcoming job insecurities and fatigue should be further investigated to help employees and organisations deal with this problem. Further research may include variables with regard to organisational practices that help employees in reducing perceptions about job insecurity and fatigue. This, in turn, reduces employees' intentions to quit. 
International Journal of Innovation, Creativity and Change. www.ijicc.net Volume 12, Issue 6, 2020

\section{REFERENCES}

Abelson, M. A.(1987). Examination of avoidable and unavoidable turnover. Journal Of Applied Phsychology, 72 (1): 382-386

Abrams, D., Ando, K. and Hinkle, S. (1998). Psychological attachment to the group: Cross cultural differences in organizational identification and subjective norms as predictors of workers' turnover intentions. Personality and Social Psychology Bulletin, 81 (6), 1027-39.

Ali, H., Jahanzaib, H., and Akbar, A. (2012). Employees burnout and intention to leave: in set of banking organizations in pakistan. Asia Pacific Journal of Research in Business Management, 3 (9). 425-441.

Ahmad, A., \& Afgan, S. (2016). The relationship of job stress and turnover intention in

commercial banks of Pakistan by assessing the mediating role of burnout. Journal of Business Strategies, 10(1), 14-35

Ashford, S.J., Lee, C., and Bobko, P. (1989). Content, causes and consequences of job insecurity: A theory-based measure and substantive test. Academy of Management Journal, 32 (4), 803-829.

Armstrong, M., \& Taylor, S. (2014). Armstrong's Handbook of Human Resource

Management Practice. Kogan Page Publishers.

Bosman, J., Buitendach, J. H., and Laba, K. (2006). Job insecurity, burnout and organisational commitment amoung employees in a financial institution in Gauteng. SA Journal Of Industrial Psychology, 31 (4) 32-40.

Boshoff, C., \& Allen, J. (2000). The influence of selected antecedents on frontline staffs perception of service recovery performance. International Journal of Service Industry Management, 11(1),63-90

Capelli, P. (1999). Career jobs are dead. California Management Review, 42 (1), 146-167.

Catalano, R., Rook, K. and Dooley, D. (1986). Labor markets and help-seeking: a test of the employment security hypothesis. Journal of Health and Social Behavior, 27, 277287.

Cheng, G.H.L., and Chan, D.K.S. (2008). Who suffers more from job insecurity? A meta- analytic review. Applied Psychology. An International Review, 57, 272-303. 
International Journal of Innovation, Creativity and Change. www.ijicc.net Volume 12, Issue 6, 2020

Chirumbolo, A. and Areni, A. (2005). The influence of job insecurity on job performance and absenteeism: The Moderating Effect of Work Attitudes. Journal of Industrial Psychology, $65-71$

Dekker, S.W. and Schaufeli, W.B. (1995). The efects of job insecurity on psychological health and withdrawal: a longitudinal study. Australian Psychologist, 30, 57-63.

Faloye, O.D., Abasilim, A.N., and Agboola, A.A. (2013). Job burnout and intention to quit: an empirical study of the Nigeria Police. International Journal of Business and Economic Development, 3, 25-36.

Firth,L., Mellor, D.J., Moore, K.A., and Loquet, C. (2004). How can managers reduce employee intention to quit? Journal of Managerial Psychology, 19 (2), 170-187.

Greenhalgh, L. \& Z. Rosenblatt. (1984). Job Insecurity: Towards conceptual clarity", Academy of Management Review, 9 (3): 438-448

Ismail,Hassan (2015) . Job insecurity, burnout and intention to quit. International Journal of Academic Research in Business and Social Sciences.5, (4), 310-324

Jogiyanto, 2011. Concept and application of structural equation modelling with variant-based in a business research. UPP STIM YPKN. Yogyakarta

Kinnunen, U., S. Mauno, J. Natti, dan M. Happonen. ( 2000). "Organizational antecedents and outcomes of Job insecurity: A longitudinal study In three organizations in Finland", Journal of Organizational Behavior, 21: 443-459

Lee, C., P. Bobko, and Z.X. Chen. (2006). Investigation of the multidimensional model of job insecurity in China and the USA. Applied Psychology: An International Review, 55 , pp. 512- 540.

Maslach, C., and Jackson, S.E. (2014). Maslach burnout inventory-human services survey. in Chigerwe, M., Boudreaux, K.A., and Ilkiw, J.E. BMC Medical Education, pp. 1-7.

Marjukka, L., Beatrice, I.J.M., Van der, H., Gustav, W., Hans-Martin, H., Peter, T. (2009). Job insecurity and intent to leave the nursing profession in Europe. International Journal of Human Resource Management, 20 (2). 420-438.

Schyns B., Torka N., Gossling T. (2007). Turnover intention and preparedness for change: Exploring leader-member exchange and occupational self-efficacy as antecedents of two employability predictors. Career Development International, 12 (7), 660-679. 
International Journal of Innovation, Creativity and Change. www.ijicc.net Volume 12, Issue 6, 2020

Schermerhorn, Jr., John R. (2005). Management. New York: John Wiley \& Sons, Inc.

Swider, B.W., and Zimmerman, R.D. (2010). Born to burnout: a meta-analytic path model of personality, job burnout, and work outcomes. Journal of Vocational Behavior, 76, pp.487-506.

Tamini, B. K., \& Kord, B. (2011). Burnout components as predictors of job \& life satisfaction of university employees. Indian Journal of Industrial Relations, 47 (1) 126-137.

Thomas, S., and Cornelius, J. (2010). A model for the effects of job insecurity on performance, turnover intention, and absenteeism. Journal of Occupational and Organizational Psychology, 83, pp. 101-117.

Utami, Intiyas , Nur Endah S. (2008). The effect of job insecurity, job satisfaction, and organizational commitment on job turnover. Accounting Conference, The $2^{\text {nd }}$ Accounting \& The $1^{\text {st }}$ Doctoral Colloquium 4-5 November.

Waruwu, AW and Y., A., B., Nugroho. (2018). The effect of job stress, on turnover intention with burnout as mediating variable: A study on employees at BPJS offices. Proceeding 91 